\title{
Study Of Understanding Types Of Occupational Students End Of Semester Of Indonesian Language And Literature Education Study Programs In Banda Aceh
}

\author{
Faisal \\ \{faisal@serambimekkah.ac.id\} \\ Universitas Serambi Mekkah
}

\begin{abstract}
This research was conducted with the aim of describing the politeness of the speech acts of students in the final semester of Indonesian Language and Literature Education in Banda Aceh. The focus of this research is what kind of politeness is used by students in the last semester of Indonesian Language and Literature Education in Banda Aceh in communicating daily. This research was conducted with a qualitative approach. This research is a type of field research. The research was carried out with six stages: (1) creating and distributing data source data instruments, (2) grouping the results of data collection as a reference for data collection, (3) recording student communication during free hours or resting; when in a public place such as canteen and waiting room, class time when there is no lecture (4) transcribing record data into written data, (5) analyzing carefully and describing the results of the analysis, (6) calculating the percentage of appearance of every sub-subject of politeness not the speech used by students in the final semester of Indonesian Language and Literature Education in Banda Aceh. The results showed that students in the last semester of Indonesian Language and Literature Education in Banda Aceh used 4 of 5 types of politeness of speech acts with a diverse percentage. (1) type of short length of $20 \%$. (2) type of speech sequence $4.7 \%$, (3) type of intonation and kinesika 9, 4\%, and (4) type of impression markers of 8.6\%. However, the final semester students of Indonesian Language and Literature Education in Banda Aceh did not use types without politeness. It can be concluded that students in the last semester of Indonesian Language and Literature Education in Banda Aceh use 4 of the 5 types of speech acts politeness in communicating daily.
\end{abstract}

Keywords: politeness, speech acts, students, and final semester

\section{Introduction}

This study wants to find out the final semester student readiness related to the application of polite communication as a provision for educating. The final semester students are students who have academically studied language proficiency (in Pragmatics). They have known the scope, types of politeness, strategies, and deviations of the politeness principle of speech acts. Because they have passed the course, an action is needed to evaluate learning outcomes in the form of direct practice in daily life. This study examines the use of politeness in speech acts for students who have taken Pragmatic courses in which politeness of speech acts is taught. The politeness of speech acts is the activity of communicating with speech partners from various social settings and situations which requires the existence of norms of courtesy. To produce graduates / prospective teachers who are good (polite) in communication is necessary 
evaluation of adequate learning outcomes. There are four markers that can be used to measure language politeness as stated by [1] namely a short length of speech, sequence of speech, intonation and kinesic sign, expression of politeness and without type without politeness. The use of politeness markers can be used as indicators of student communication politeness in the final semester of Indonesian Language and Literature Education in Bnada Aceh. If all markers are used, the communication of the final semester students can be categorized as polite.

\section{Research Method}

The following is a summary of the literature sources referred to in this study based on research problems.

(1) Speech acts are all forms of speech which means actions, such as asking, explaining, pleading, giving orders, and prohibiting based on [2], [3], [4] and others -other.

(2) The politeness of speech acts is a conscious attitude that gives rise to the protection of the dignity of the speaker and the interlocutor and maintains the harmony of social communication based on the theories of [2], [3], [4] and others.

Speaking is a social activity. Speaking involves humans in general as social groups. Speaking does not distinguish between ethnicity and skin color. Every social group has a different culture. Cultural diversity is reflected in language. Speaking in accordance with cultural norms will produce language politeness (Muslich, 2006: 2). When communicating with people one must pay attention to cultural norms and politeness

Speakers and speech partners must understand each other's rules governing actions, the use of language, and interpretation of actions or speech. These rules aim to create language politeness. Speaking is a form of communication that is most widely practiced in human daily life. Speaking which means action is called a speech act. Speech acts are speech that means actions, such as asking, explaining, asking, giving orders, prohibiting, and so on (Searle in Santoso, 2013). A person's form of communication is directly proportional to the knowledge gained. Knowledge acquisition is a thought that is always criticized. Students as knowledgeable people are directed to be polite, religious, and develop values in social activities with knowledge gained. Therefore, the ability to communicate politely for prospective teachers is very important before engaging in school education.

Based on the Big Indonesian Dictionary (2008: 462), language politeness is a variety of languages used in social situations that require the existence of norms of courtesy. Good words mean good language and good behavior. Language and behavior modesty has a close relationship. In social life, modesty is the key to the benefits of an action.

In order to achieve successful communication, it requires understanding of the ideal communication standards that apply in a society. Wijana in [5] said that a speech that is conveyed indirectly and tends to be long is generally considered a polite attitude to the speech partner. Politeness, language, and social reality are components that cannot be separated. Decency has tied language and social reality.

Communication activities conducted by the final semester students can be in the form of explanation, request, essay, etc. The activity is action. So, speech that contains actions is called speech acts. No speech is a speech activity which means actions which involve speakers and speech partners [2], [3], [6], [1] suggests that there are four markers that can be used to measure politeness of speech acts. There is an assumption in the life of the Indonesian people that speaking should not be too short because it can be impressively rude. Enforcement, the 
shorter the speech, the more potential to be rude When someone shortens his speech by taking the core of tutura alone, modesty or positive ado is reduced even none. Can be understood further by looking at the following example.

(a) "Baju itu!"

(b) "Ambil baju itu!"

(c) "Ambilkan baju itu!"

(d) "Tolong ambilkan baju itu!"

(2) Speech Order

The speech sequence has the potential to smooth and make a speech rough. Therefore, the dominant person weighs the order of words that will be issued to communicate, such as communicating students with teachers, son-in-law with in-laws and others. Can be further understood from the following example.

(a) " Rumah ini mau dipakai. Bersihkan cepat!" (more polite)

(b) "Bersihkan cepat! Rumah ini mau dipakai."(More rough)

"Clean fast! This house wants to be used."

(3) Intonation and Kinesika Signs

In the study of intonation, each sentence has a different intonation between one utterance and another. When the intonation of a word is extended, the meaning is different from the one that is shortened by its intonation. Intonation is long pende, high lace, soft soft sound, rhythm and pause. In addition to intonation, there are other markers that influence politeness, namely paralinguistic elements or text, such as facial expressions, posture, hand movements, shoulder movements, head nods and others.

(4) Expression of Politeness Markers.

Politeness is very easy to build using politeness markers. Likewise to reduce levels of politeness, just remove the markers of politeness. Some of the modesty markers commonly used in Indonesian communication are the words ayo, coba, mari, mohon, hendaknya, silakan, etc.

\section{Result and Discussion}

This research was conducted with a qualitative approach. This research is a type of field research. The research was carried out with six stages: (1) creating and distributing data source data instruments, (2) classifying the data collection as a reference for data collection, (3) recording student communication during free hours or resting; when in public places such as canteen and waiting room, class time when there is no lecture (4) transcribing record data into written data, (5) analyzing carefully and describing the results of the analysis, (6) calculating the percentage of appearance of each sub-subject of politeness not said which is used by students in the final semester of Indonesian Language and Literature Education in Banda Aceh. This research will be conducted at the Indonesian Language and Literature Education Study Program at Syiah Kuala University and the Indonesian Language and Literature Education Study Program at Serambi Mekkah University. Serambi Mekkah University was chosen as a representation of a private university in Banda Aceh, while Syiah Kuala University was a representation of a public university in Banda Aceh. The sources of data for this study were students in the final semester (semester 7 and 8) of Indonesian Language and Literature Education at Syiah Kuala University and students in the final semester (semester 7 and 8) of Indonesian Language and Literature Education at Serambi Mekkah University. 
To get accurate data, researchers used several tools to collect data: (1) stationery; (2) data source data forms; (3) research data retrieval form, which is a form that contains participant data every one recording that must be filled in by the recorder, namely the supporting researcher, including: recording time, recording place, participants, and the topic discussed; (4) tape recorder. To analyze this research data, a number of stages of analysis are needed as follows. First, the author transcribes the oral data that has been collected. Second, the data that has been transcribed is grouped based on (1) the types of politeness of speech acts according to Rahardi's classification (1999: 16). Third, the research data is analyzed and described by theories that are in accordance with the problem under study. Fourth, calculate the percentage of data appearance of the review of each research problem which includes the type of politeness of speech acts, politeness strategies of speech acts, and irregularities in the principle of politeness of speech acts.

The types of politeness of speech acts are classified into five types, namely (1) short length of speech acts, (2) sequence of speech acts, (3) intonation and kinesic cues, and (4) politeness markers. (5) without politeness. The following are described one by one.

1. Long Short Actions in Speech

Short length politeness of speech acts is the level of politeness of speech acts influenced by the short length of speech acts. Longer speech acts have higher levels of politeness than short speech acts. Short-length politeness of speech acts can be observed by analyzing the core of a sentence. If there is an addition of other elements in the form of words, phrases, or clauses that exceed the minimum standard of a sentence, the sentence has the potential to analyze the short-term politeness of the speech act. That is, the speech act causes differences in politeness levels when used by its core rather than the whole sentence. Speech acts that are considered more polite because they are longer can be observed from the addition of other elements that are not mandatory in the main speech acts, namely the addition of words, phrases, and clauses. Examples of speech acts can be observed in the following explanation.

In the following speech acts there is an extension of speech acts with the addition of words. The application is like adding words Ina tunggu apa Na? on basic speech acts. To understand more deeply, the following explanation can be considered.

(1) Ina tunggu apa $\mathrm{Na}$ ?

What are you waiting for $\mathrm{Na}$.

Text of speech acts (1) is a form of action to ask the purpose of the speakers who are sitting in front of the study program. The speaker aims to pay attention to the opponent who is waiting.

(1a) Ina tunggu apa?

What are you waiting for?

Speech acts (1) have high levels of politeness compared to speech acts (1a). The term emergence that occurs in speech acts (1a) is due to the speech acts only using the core meaning of a speech. Without the addition of the word $\mathrm{Na}$, speech acts seem firm without further ado. Small talk is commonly used as a way to convey a purpose of speech acts so that they are easily accepted and make speech partners comfortable. Because it involves talking partners directly in speech acts by mentioning their names. Speech partners feel respected and appreciated for their comfort as people who have the competence to communicate. In addition, the speech act clarifies the communication reference so that speakers are not potentially overlooked with the communication rhythm that tends to change.

2. Order of Speech Acts

The orderliness of speech acts is the level of politeness of speech acts that are influenced by the composition of words, phrases, or clauses in a sentence. The use of the politeness 
sequence of speech acts can be traced from the changes in meaning generated when the sequence of speech acts is repositioned. The change in politeness rating referred to is the level of politeness of the repositioning speech acts to be reduced compared to the original speech acts. Pay attention to the following speech acts.

(2) Jam berapa udah woi.

What time has it been?

Sentence (2) is the result of the questioning done by the speaker. The action was taken when the addressee was over lunch in a cafeteria on campus. Speakers are in dire need of information about time. The speaker aims to request immediate information regarding the time.

(2a) Woi, jam berapa udah?

Woi, what time is it?

The speech act is a rough speech act if it is studied with the standard of politeness of agefree speech acts. In students' speech acts students in a certain time and environment, speech acts (2) are categorized as more polite than speech acts that have been linguistically repositioned. (2a) has lower levels of politeness compared to previous speech acts. This occurs because there is a reposition of the pronoun partner / speech target from the end of the sentence to the beginning of the sentence. The speech situation also makes the politeness rating decrease. Speech acts (2) are more polite than speech acts that match the situation / speech situation after the target markers speak as in speech acts (2a). It can be concluded that politeness in speech acts in the context of speech acts is influenced by how closely the speech target is and how close the mention of the condition / speech situation is. The closer the mention is, the lower the politeness value is generated.

3. Intonation and Kinesika Signal

The politeness of the speech acts of the final semester students is a politeness standard that uses intonation as a measure. Friendly intonation and pleading intonation is a form of intonation in which the dominant application has politeness value. The politeness of the speech acts of the final semester students can be found in various speech acts. Here's the explanation.

(3) Aku mau mulai nulis lah, gimana ni?

I want to start writing, how is this?

(-alternation: data attachment 2)

Sentence (19) is a visualization of the action of finding a solution to the problem at hand. The speaker asks how to start to write the final assignment. Speakers hope to get enlightenment on the problems faced by their speech partners.

Speech acts (3) use intimate and friendly intonations to find solutions so that they give birth to a polite attitude. Politeness moves dynamically according to intonation, either using friendly, somewhat friendly, or unfriendly intonation. (3) speech acts are polite because the speech partner is asked very much to help speakers. Speech partners feel that only those are needed at that time to find speakers' solutions. If a speaker is not helped can be sad. There is a feeling of mixedness in this condition, first the speech partner helps the speaker by being asked. Second, the speech partner feels affection or pity with the condition of the speaker if he is not helped. The politeness of speech acts (3) is also influenced by the use of words like this? which affirms that the speakers really want their speech partners to see and give input or solutions. If the word how is removed and the intonation is changed, one form of modesty changes in speech acts will look like in the following example.

(3a) Aku mau mulai nulis lah.

Speech acts can be rude and disrespectful according to changes in intonations that arise. 


\section{Politeness Markers}

The use of politeness markers is one way to improve politeness of speech acts. Decency is influenced by the presence or absence of politeness markers. The markers cause differences in the ranking of the decency of a speech act after and before its use. If it does not cause a ranking of politeness, the added element is not a sign of politeness.

The use of politeness markers in speech acts can be in the form of politeness in the form of general words, markers of politeness in the form of religious terms, and other signs of politeness. The following is the explanation.

(4) Astagfirullah, tidak bersyukur. Astagfirullah, not grateful.

Sentence (4) is a form of evaluating the speech of a fellow speaker. When communicating with two colleagues, the speaker heard complaints from a speaker regarding a gift. Speakers seem to complain about something The speaker's goal is to reprimand a friend who complains about something.

\section{(4a) Tidak bersyukur}

Not grateful

Speech acts (4) use astagfirullah politeness markers. The speech acts have a high level of politeness so that they are directly related to self-servitude to God by asking forgiveness. This action makes the speech partner not argue to justify themselves. Speakers feel they have received treatment in the form of correct reprimands. Conversely, if the politeness markers are not used, as in no. (4a) speech acts are very heavy because they are like verdicts. In general, humans do not like being sentenced.

\section{Conclusion}

Based on the entire series of research stages it can be concluded that the final semester students of Indonesian Language and Literature Education in Banda Aceh used four of five types of politeness speech acts, namely types of short lengths of speech $20 \%$, type of speech utterances $4.7 \%$, types of intonation and kinesic cues $9,4 \%$, and politeness markers $8.6 \%$. Thus, it can be stressed that the final semester students of Indonesian Language and Literature Education Study Program in Banda Aceh have communicated with satun / have politeness in speech acts. The form is, the final semester students use 4 of the 5 types of speech acts politeness expressed by experts.

\section{References}

[1] K. Rahardi, Pragmatik Kesantunan Imperatif Bahasa Indonesia. Yogyakarta: PT. Glora Aksara Pratama, 2005.

[2] J. L. Austin, How to do Things With Words. : Oxford: Oxford University Press, 1962.

[3] J. R. Searle, Expression And Meaning. New York: Cambridge University Press, 1979.

[4] G. Leech, Prinsip-Prinsip Pragmatik. Jakarta: Universitas Indonesia, 1993.

[5] R. Setyawati, "Kesantunan Berbahasa dalam Pembelajaran di Kelas." Publikasi Ilmiah UMS, 2013.

[6] Djajasudarma, Wacan dan Pragmatik. Bandung: PT Refika Aditama, 2012. 